\title{
Herpes Simplex Virus Encephalitis: An Update
}

\author{
Herpes Simpleks Virüs Ensefaliti: Bir Güncelleme
}

\author{
(D) Jean Paul STAHL1, (D) Alexandra MAILLES2 \\ 1 European Study Group on Infections of the Brain; University and CHU of Grenoble, Department of Infectious Diseases, Grenoble, France \\ 2European Study Group on Infections of the Brain; Santé Publique France, Saint Maurice, France
}

\section{Abstract}

Herpes simplex virus (HSV) is the most frequent cause of sporadic infective encephalitis in adults. Despite antiviral therapies, the case fatality rate is moderate to high ( 5 to $30 \%$ according studies and countries). Tools for diagnosis are specific polymerase chain reaction testing of the cerebrospinal fluid on one hand and magnetic resonance imaging on the other hand. Guidelines of various countries recommend systematic treatment by acyclovir $10 \mathrm{mg} / \mathrm{kg}$, three times a day, starting before microbiological confirmation. The remaining question is the usefulness of corticosteroids. This question is related to the frequency of late sequalae (30 to $40 \%$ of patients) and the recent demonstration of auto-immune encephalitis triggered by HSV encephalitis. These two possible complications suggest the usefulness of steroids as prophylactic treatment but specific clinical trials are needed for confirmation. Genetic features were recently identified, explaining encephalitis occurrence in some patients, but do not explain all cases so far. Keywords: Acyclovir, herpes simplex virus, sequelae, auto-immune encephalitis, ganciclovir

\section{Öz}

Herpes simpleks virüsü (HSV) erişkinlerde sporadik enfektif ensefalitin en sık nedenidir. Antiviral tedavilere rağmen, olgu fatalite oranı orta ila yüksek arasında değişen oranlarda (çalışma ve ülkelere göre \%5 ila \%30) değişmektedir. Tanı yöntemlerinin bir tarafında beyin omurilik sıvısında spesifik polimeraz zincir reaksiyonu testleri diğer tarafında manyetik rezonans görüntüleme yer almaktadır. Çeşitli ülkelerin tedavi rehberleri, günde üç kez sistemik $10 \mathrm{mg} / \mathrm{kg}$ asiklovir tedavisinin mikrobiyolojik doğrulama beklenmeden başlanmasını önermektedir. Diğer bir soru kortikosteroidlerin yararlı olup olmadığıdır. Bu soru geç dönem sekel sıklığı (hastaların \%30-40'ı) ve yakın zamanda bildirilen HSV ile tetiklenen otoimmün ensefalit ile ilgilidir. Bu iki olası komplikasyonda, profilaktik tedavi olarak steroidler yararlı olabilir, ancak kesinlik kazanması için yapılacak spesifik klinik çalışmalara ihtiyaç vardır. Genetik özellikler yakın zamanda tanımlanmış ve bazı hastalardaki ensefalit oluşumunu açıklamıştır, ancak henüz tüm olguları açıklayamamaktadır.

Anahtar Kelimeler: Asiklovir, herpes simpleks virüs, sekel, otoimmün ensefalit, gansiklovir

\section{Introduction}

Encephalitis is a rare infection in western countries $^{[1]}$. The overall incidence is reported to range from 0.6 to $1.2 / 100.000$ inhabitants. Herpes simplex virus (HSV) encephalitis (HSVE) is the leading identified etiology in these countries (ranging from
$30 \%$ to more than $40 \%)^{[1-3]}$. Leading pathogen may change in some countries with outbreaks or endemic pathogens, such as Japanese encephalitis in South East Asia, for example.

The aim of this review was to highlight recent features of HSVE: diagnosis improvement, update for treatment, links with immunity disorders, and genetic risk factors.

Cite this article as: Stahl JP, Mailles A. Herpes Simplex Virus Encephalitis: An Update. Mediterr J Infect Microb Antimicrob. $2018 ; 7: 24$.

Address for Correspondence /Yazışma Adresi: Jean Paul Stahl MD, European Study Group on Infections of the Brain; University and CHU of Grenoble, Department of Infectious Diseases, Grenoble, France 


\section{Epidemiology and Burden}

In a French study performed in $2007^{[2]}$, HSV was found to be responsible from $42 \%$ of 253 cases of microbiologically identified encephalitis. When considering all the cases of encephalitis, including those with no identified agent, HSV was the cause in $22 \%$ of patients ${ }^{[2]}$. The Californian encephalitis project reported that HSV was responsible for $24 \%$ of identified cases of encephalitis from 1998 to $200{ }^{[3]}$. Worldwide, a recent literature review ${ }^{[4]}$ observed that HSV was reported to be the most frequent agent in 65\% of studies. Varicella-zoster virus was the second most frequent agent. Enteroviruses were also frequently reported and considered to be the most frequent etiology in two studies, and the $2^{\text {nd }}$ or $3^{\text {rd }}$ etiology in five other studies.

In the United States, HSVE hospitalization rate has been recently reported to be $10.3 \pm 2.2$ cases/million in neonates, $2.4 \pm 0.3$ cases/ million in children, and $6.4 \pm 0.4$ cases/million in adults. Inhospital mortality in neonates, children and adults were $6.9 \%$, $1.2 \%$ and $7.7 \%$, respectively ${ }^{[5]}$.

In any case, since any delay may impact the chance of recovery and a safe specific treatment (acyclovir) is available, HSV has to be considered a priority for an empiric treatment.

\section{Clinical Presentation}

The clinical presentation is often non specific. In a recent study ${ }^{[6]}$, fever was reported in $87 \%$ of cases only. Altered mental status was reported in all patients, accompanied by disorientation $(87 \%)$, confusion $(69 \%)$, apathy $(47 \%)$, seizures $(35 \%)$, focal neurological signs $(27 \%)$, speech disorders $(26 \%)$, decreased consciousness $(24 \%)$, agitation $(22 \%)$, hallucinations $(13 \%)$, impaired cranial nerves (11\%), aggressiveness (7\%), involuntary abnormal movements (4\%), and spatial neglect (2\%). Coma was reported in $4 \%$ of cases. Meningism was present in 25\%. Initial mechanical ventilation was required in 16\% of cases. In developed countries, case fatality rate (CFR) ranges from 5 to $30 \%$.

\section{Current Recommendation for Diagnosis}

\section{Clinical Diagnosis}

Encephalitis has been defined $a s^{[7]}$ the presence of a major criterion (patients presenting to medical attention with altered mental status i.e. decreased or altered level of consciousness, lethargy or personality change lasting $\geq 24$ hours with no alternative cause identified) accompanied by 2 (possible encephalitis) or 3 and more (probable or confirmed encephalitis) minor criteria. These minor criteria are:
- Documented fever $\geq 38{ }^{\circ} \mathrm{C}$ within 72 hours before or after presentation,

- Generalized or partial seizures not fully attributable to a preexisting seizure disorder,

- New-onset focal neurologic findings,

- Cerebrospinal fluid (CSF) white blood cells count $\geq 5 / \mathrm{mm}^{3}$,

- Abnormality of brain parenchyma on neuroimaging suggestive of encephalitis that is either new from prior studies or appears acute in onset.

- Abnormality on electroencephalography (EEG) that is consistent with encephalitis and not attributable to another cause.

This definition was proposed by the International Encephalitis Consortium, and the objective was to provide a clear and simple definition for studies, as to be able to compare data.

\section{Laboratory Diagnostics}

Lumbar puncture (LP) for HSV polymerase chain reaction (PCR) and magnetic resonance imaging (MRI) are emergency procedures in case of encephalitis, as any delay in brain imaging is a risk factor for delayed treatment ${ }^{[8]}$.

When using as gold standard the result of brain biopsy, brain biopsy has been recommended for suspected HSVE, and is the gold standard, so far ${ }^{[8,9]}$. Cerebrospinal fluid HSV PCR is currently the standard biological test for HSVE diagnosis.

Polymerase chain reaction may show false negative results in HSVE patients when carried out in a CSF sample taken during the first four days of the disease. In such situation, another sample, obtained after those four days, should be tested ${ }^{[10,11]}$. Nevertheless, false negative PCR results may be obtained in less than $0.4 \%$ of patients with HSVE.

Polymerase chain reaction is not recommended for the evaluation of the clinical effects of acyclovir treatment.

It is difficult to report the clearance of HSV in CSF, as LP is not currently performed in patients with a good outcome. We have only few reports of patients experiencing a bad evolution. It is not said like this in a recent study, but we can assume that it was the case: with 4 of 17 (24\%) patients with positive initial HSV $1 / 2$ PCR findings that were still positive after day $7^{[12]}$. In another study, in 18 patients, HSV PCR was reported positive from 9 to 28 days after initiation of acyclovir, but it was not correlated with an unfavorable outcome ${ }^{[13]}$.

Imaging

Imaging is the other key tool for diagnosis. Magnetic resonance imaging should be the first-line tool for investigation of 
encephalitis, as it is far more sensitive and specific than computed tomography. A recent review ${ }^{[14]}$ summarized current knowledge about modern imaging in HSVE. Brain MRI has a high sensitivity for the diagnosis of HSVE, showing brain abnormalities in 80 to $100 \%$ of cases. However, normal brain images on MRI, although rare in HSVE patients, do not rule out HSVE diagnosis. Herpes simplex virus encephalitis typically affects the limbic system, most frequently the medial temporal lobes, but also the insular, cingulate and fronto-basal cortex. Lesions were bilateral before the use of acyclovir, but now are unilateral in $64-68 \%$ of cases. Brain MRI typically shows hyper-intensities involving the cortex and the white matter on T2 and FLAIR images. Areas of contrast enhancement can also be present.

The frequent seizures associated with HSVE may also lead to reversible hyper-intense FLAIR signal in the thalamus. Isolated brainstem involvement is rare. Diffusion-weighted imaging (DWI) seems to be the most sensitive sequence for detecting HSVE in the acute phase, typically showing hyper-intense lesions with restricted apparent diffusion coefficient (ADC). In the subacute phase of treated HSVE ( $>10$ days), the ADC decreases and DWI seems less sensitive than T2 and FLAIR imaging for lesion depiction ${ }^{[15]}$. Severe presentations of HSVE show cortical and subcortical extensive lesions reflecting the hemorrhagic necrosis, and characterized by hypo-intense $2^{*}$ signal, but lobar hematoma is rare. Extensive lesions on MRI are associated with a poor prognosis.

EEG is more frequently recommended to investigate seizures, status epilepticus, and consciousness disorder, than to diagnose encephalitis, as it is difficult to obtain it in emergency cases ${ }^{[16]}$.

\section{Current Recommendation for Treatment}

United States ${ }^{[8]}$, French ${ }^{[16]}$, United Kingdom ${ }^{[17]}$, and Australian ${ }^{[18]}$ guidelines propose similar recommendations: in adult patients, acyclovir should be administered at a dose of $10 \mathrm{mg} / \mathrm{kg} / 8$ hours (30 mg/kg/day) for 14 days in immunocompetent patients and 21 days in immunocompromised patients. The objective is to achieve plasma concentrations of $3 \mathrm{mg} / \mathrm{l}$ or above to ensure a CSF concentration of $1 \mathrm{mg} / \mathrm{l}$, even though monitoring of plasma concentrations is usually cannot performed. The outcome is correlated with the delay before the initiation of acyclovir. After a retrospective but large study, it seems that a threshold at day two after the onset could be proposed ${ }^{[19-21]}$. A recent study did not observe any improved neurological prognosis with $15 \mathrm{mg} /$ $\mathrm{kg} / 8$ hours $^{[6]}$.

Resistance to acyclovir due to mutation in the thymidine kinase gene may be observed, most frequently in immunocompromised patients but there are few case reports including immunocompetent patients ${ }^{[2,23]}$. Reported alternative treatments used are foscarnet and ganciclovir.

\section{Outcome, Sequalae and Risk Factors}

Before the use of acyclovir, the case fatality rate of HSVE was up to $70 \%$. Thanks to this antiviral treatment, it has decreased below 20\% but survivors still experience severe sequelae. HSVE affect mainly the cognitive functions, mood, and behaviuor. Persistent neurological motor or sensory symptoms are rare. The most frequent sequelae after HSVE are memory impairment and language disorders (aphasia, agnosia, etc.). Behavioral sequelae can result in inappropriate behavior, disinhibition, and violent outbursts.

Five-hundred-one patients with proven HSVE (positive molecular diagnosis) were included in a multicentric multinational study (35 referral centers in 10 countries). Two hundred and thirty two (52.9\%) patients experienced unfavorable outcomes, 44 died, and 188 survived with sequelae. Age [Odds ratio (OR): 1.04; 95\% confidence interval (CI): 1.02 to 1.05], Glasgow coma scale score (OR: $0.84 ; 95 \% \mathrm{Cl}: 0.77$ to 0.93 ), and symptomatic periods of 2 to 7 days (OR: $1.80 ; 95 \% \mathrm{Cl}: 1.16$ to 2.79 ) and $>7$ days (OR: 3.75 ; $95 \% \mathrm{Cl}: 1.72$ to 8.15$)$ until the initiation of adequate treatment were significantly related to unfavorable outcomes ${ }^{[24]}$.

In a French study, only $40 \%$ of patients presenting with encephalitis of any cause fully recovered ${ }^{[21]}$. Mortality rate has been reported to be $5 \%$ in HSV encephalitis ${ }^{[6]}$. The authors concluded that sequalae are much more frequent than usually evaluated by physicians. Specific screening and management are necessary in the future.

\section{HSVE and Auto Immune Encephalitis}

An association between HSVE and auto-immune encephalitis was reported firstly in a case-series, performed with few patients ${ }^{[25]}$. The authors wondered if HSV could trigger the autoantibody secretion and by the way be responsible of limbic encephalitis, first described as paraneoplasic presentation by Tüzün and Dalmau ${ }^{[26]}$. It is now well established that these cases of encephalitis are also frequently diagnosed in patients without any tumor ${ }^{[27]}$. In the study by Armangue et al. ${ }^{[25]}$, five patients presented with recurrent encephalitis initially diagnosed as HSVE during the first episode. Autoantibody secretion was assessed in all of them during the second episode.

A prospective follow-up (two-three weeks after discharge and three months after) and looking for autoantibody secretion was performed in a Swedish study ${ }^{[28]}$ in which 49 patients with proven HSVE was treated by acyclovir. Antibodies against the $\mathrm{N}$-methyl-D-aspartate receptor (NMDAR) were detected in 12 of 49 patients. None were antibody-positive in the initial stage of the disease. In 10 of 12 positive cases, specific antibodies were detectable only after three months. Notably, the development 
of NMDAR autoantibodies was associated with significantly impaired recovery neurocognitive performance. After 24 months of follow-up, the median increase in Mattis Dementia Rating scale total score was 1.5 and 10 in antibody-positive and -negative participants, respectively $(p=0.018)$. This study clearly demonstrates autoantibody secretion in patients presenting with HSVE.

As a consequence, recent guidelines recommend looking for autoantibody secretion in CSF in case of failure of the antiviral treatment or recurrence of symptoms ${ }^{[16]}$.

The most recent study on this HSV trigger concluded that there was a predictable time frame of approximately five weeks in which 27\% of patients with HSE develop immune responses against NMDAR and other neuronal surface proteins ${ }^{[29]}$.

\section{Genetic Features and Future Concerns}

Genetic screenings in children with HSVE demonstrated that mutations in the toll-like receptor 3 (TLR3) gene or in other genes participating to the TLR3 pathway (TLR3, TICAM1, TRAF3, UNC93B1, TBK1, and IRF3) are risk factors for HSVE ${ }^{[30]}$.

Recently, Sironi et al. ${ }^{[31]}$ reported the same findings in adults presenting with HSVE as well as varicella zoster virus encephalitis. The small number of studied patients makes this finding to be validated by further studies, but it is a trend for explanation of some HSVE by genetic risk factors.

Another finding is interesting as it could lead to a possible future additional treatment ${ }^{[32]}$. It has been demonstrated that there was a specific loss of mitochondrial transcription before nuclear and cell damages. Minocycline maintains transcription and its related enzymatic activity, as well as astrocytes' viability.

A recessive autosomal deficit of intracellular UNC93B protein has been described in two children with $\mathrm{HSVE}^{[33]}$. They presented with a deficit of the interferon-a/b and cellular antiviral response. Herpes simplex virus encephalitis developed in these cases probably due to a single gene deficit, that does not induce any deficiency for other pathogens. The potential result could be treatment using recombinant interferon- $\alpha$.

Finally, despite an early management and antiviral treatment, some patients still experience extensive cortical necrosis. The possible benefit of steroids at anti-inflammatory dosage has been hypothesized for the prevention of necrosis. A clinical trial is currently ongoing in the UK and France ${ }^{[34]}$.

\section{Conclusion}

Herpes simplex virus encephalitis is not only an infectious disease. It is probably the result of genetic disorders, at least in some patients, and may trigger for an immune disease. The management is becoming more complex while these questions need answers i) are corticosteroids or other drugs influencing immunity useful ii) how should we organize the management of patient after the "infectious cure" for reducing sequelae?

\section{Ethics}

Peer-review: Externally and internally peer-reviewed.

\section{Authorship Contributions}

Concept: J.P.S., A.M., Design: J.P.S., A.M., Data Collection or Processing: J.P.S., A.M., Analysis or Interpretation: J.P.S., A.M., Literature Search: J.P.S., A.M., Writing: J.P.S., A.M.

Conflict of Interest: No conflict of interest was declared by the authors.

Financial Disclosure: The authors declared that this study received no financial support.

\section{References}

1. Granerod J, Tam CC, Crowcroft NS, Davies NW, Borchert M, Thomas SL. Challenge of the unknown. A systematic review of acute encephalitis in non-outbreak situations. Neurology. 2010;75:924-32.

2. Mailles A, Stahl JP; Infectious encephalitis in France in 2007: a national prospective study. Clin Infect Dis. 2009;49:1838-47.

3. Glaser CA, Honarmand $S$, Anderson $\sqcup$, Schnurr DP, Forghani B, Cossen CK Schuster FL, Christie L, Tureen JH. Beyond viruses: clinical profiles and etiologies associated with encephalitis. Clin Infect Dis. 2006;43:1565-77.

4. Boucher A, Herrmann JL, Morand P, Buzelé R, Crabol Y, Stahl JP, Mailles A. Epidemiology of infectious encephalitis causes in 2016. Med Mal Infect. 2017;47:221-35

5. Modi S, Mahajan A, Dharaiya D, Varelas P, Mitsias P. Burden of herpes simplex virus encephalitis in the United States. J Neurol. 2017;264:1204-8.

6. Stahl JP, Mailles A, De Broucker T; Steering Committee and Investigators Group. Herpes simplex encephalitis and management of acyclovir in encephalitis patients in France. Epidemiol Infect. 2012;140:372-81.

7. Venkatesan A, Tunkel AR, Bloch KC, Lauring AS, Sejvar J, Bitnun A, Stahl JP, Mailles A, Drebot M, Rupprecht CE, Yoder J, Cope JR, Wilson MR, Whitley RJ, Sullivan J, Granerod J, Jones C, Eastwood K, Ward KN, Durrheim DN, Solbrig MV, Guo-Dong L, Glaser CA; International Encephalitis Consortium. Case definitions, diagnostic algorithms, and priorities in encephalitis: consensus statement of the international encephalitis consortium. Clin Infect Dis. 2013;57:114-28.

8. Tunkel AR, Glaser CA, Bloch KC, Sejvar JJ, Marra CM, Roos KL, Hartman BJ, Kaplan SL, Scheld WM, Whitley RJ; Infectious Diseases Society of America. The management of encephalitis: clinical practice guidelines by the Infectious Diseases Society of America. Clin Infect Dis. 2008;47:303-27.

9. Tebas $\mathrm{P}$, Nease RF, Storch $\mathrm{GA}$. Use of the polymerase chain reaction in the diagnosis of Herpes simplex encephalitis: a decision analysis model. Am J Med. 1998;105:287-95.

10. Poissy J, Wolff M, Dewilde A, Rozenberg F, Raschilas F, Blas M, Georges $\mathrm{H}$, Chaffaut $\mathrm{C}$, Yazdanpanah Y. Factors associated with delay to acyclovir administration in 184 patients with herpes simplex virus encephalitis. Clin Microbiol Infect. 2009;15:560-4.

11. Guffond T, Dewilde A, Lobert PE, Caparros-Lefebure D, Hober D, Wattre P. Significance and clinical relevance of the detection of herpes simplex virus 
DNA by the polymerase chain reaction in cerebrospinal fluid from patients with presumed encephalitis. Clin Infect Dis. 1994;18:744-9.

12. Kleines M, Scheithauer S, Schiefer J, Häusler M. Clinical application of viral cerebrospinal fluid PCR testing for diagnosis of central nervous system disorders: a retrospective 11-year experience. Diagn Microbiol Infect Dis. 2014;80:207-15.

13. Kamei S, Takasu T, Morishima T, Mizutani T. Serial changes of intrathecal viral loads evaluated by chemiluminescence assay and nested PCR with acyclovir treatment in herpes simplex virus encephalitis. Inter Med. 2004;43:796-801.

14. Bertrand A, Leclercq D, Martinez-Almoyna L, Girard N, Stahl JP, De-Broucker T. MR imaging of adult acute infectious encephalitis. Med Mal Infect. 2017;47:195-205

15. Sawlani V. Diffusion-weighted imaging and apparent diffusion coefficient evaluation of herpes simplex encephalitis and Japanese encephalitis. J Neurol Sci. 2009;287:221-6.

16. Stahl JP, Azouvi P, Bruneel F, De Broucker T, Duval $X$, Fantin B, Girard N, Herrmann JL, Honnorat J, Lecuit M, Mailles A, Martinez-Almoyna L, Morand $\mathrm{P}$, Piroth $\mathrm{L}$, Tattevin $\mathrm{P}$; reviewing group. Guidelines on the management of infectious encephalitis in adults. Med Mal Infect. 2017;47:179-94.

17. Solomon T, Michael BD, Smith PE, Sanderson F, Davies NW, Hart IJ, Holland M, Easton A, Buckley C, Kneen R, Beeching NJ; National Encephalitis Guidelines Development and Stakeholder Groups. Management of suspected viral encephalitis in adults--Association of British Neurologists and British Infection Association National guidelines. J Infect. 2012;64:347-73.

18. Britton PN, Eastwood K, Paterson B, Durrheim DN, Dale RC, Cheng AC, Kenedi C, Brew BJ, Burrow J, Nagree Y, Leman P, Smith DW, Read K, Booy $\mathrm{R}$, Jones CA; Australasian Society of Infectious Diseases (ASID); Australasian College of Emergency Medicine (ACEM); Australian and New Zealand Association of Neurologists (ANZAN); Public Health Association of Australia (PHAA). Consensus guidelines for the investigation and management of encephalitis in adults and children in Australia and New Zealand. Intern Med J. 2015;45:563-76.

19. Erdem $H_{1}$ Cag $Y$, Ozturk-Engin D, Defres $S$, Kaya $S$, Larsen $L$, Poljak $M$, Barsic $B$, Argemi X, Sørensen SM, Bohr AL, Tattevin P, Gunst JD, Baštáková L, Jereb M, Johansen IS, Karabay O, Pekok AU, Sipahi OR, Chehri M, Beraud G, Shehata G, Del Vecchio RF, Maresca M, Karsen H, Sengoz G, Sunbul M, Yilmaz G, Yilmaz H, Sharif-Yakan A, Kanj SS, Parlak E, Pehlivanoglu F, Korkmaz F, Komur S, Kose S, Ulug M, Bolukcu S, Coskuner SA, Ince N, Akkoyunlu $Y$, Halac G, Sahin-Horasan E, Tireli H, Kilicoglu G, Al-Mahdawi A, Nemli SA, Inan A, Senbayrak S, Stahl JP, Vahaboglu H. Results of a Multinational Study Suggest the Need for Rapid Diagnosis and Early Antiviral Treatment at the onset of Herpetic Meningoencephalitis. Antimicrob Agents Chemother. 2015;59:3084-9.

20. Whitley RJ. Herpes simplex encephalitis: adolescents and adults. Antiviral Res. 2006;71:141-8.

21. Mailles A, De Broucker T, Costanzo P, Martinez-Almoyna L, Vaillant V, Stahl JP; Steering Committee and Investigators Group. Long-term outcome of patients presenting with acute infectious encephalitis of various causes in France. Clin Infect Dis. 2012;54:1455-64.

22. Schulte EC, Sauerbrei A, Hoffmann D, Zimmer C, Hemmer B, Mühlau M. Acyclovir resistance in herpes simplex encephalitis. Ann Neurol. 2010;67:830-3.
23. Sauerbrei A. Acyclovir resistance in herpes simplex virus type I encephalitis: a case report. J Neurovirol. 2017;23:638-9.

24. Cag Y, Erdem H, Leib S, Defres S, Kaya S, Larsen L, Poljak M, Ozturk-Engin D, Barsic B, Argemi X, Sørensen SM, Bohr AL, Tattevin P, Gunst JD, Baštáková L, Jereb M, Johansen IS, Karabay O, Pekok AU, Sipahi OR, Chehri M, Beraud G, Shehata G, Fontana R, Maresca M, Karsen H, Sengoz G, Sunbul M, Yilmaz G, Yilmaz H, Sharif-Yakan A, Kanj S, Parlak E, Pehlivanoglu F, Korkmaz F, Komur S, Kose S, Ulug M, Bolukcu S, Coskuner SA, Stahl JP, Ince N, Akkoyunlu Y, Halac G, Sahin-Horasan E, Tireli H, Kilicoglu G, Al-Mahdawi A, Nemli SA, Inan A, Senbayrak S, Vahaboglu H, Elaldi N. Managing atypical and typical herpetic central nervous system infections: results of a multinational study. Clin Microbiol Infect. 2016;22:568.

25. Armangue T, Moris G, Cantarin-Extremera V, Conde CE, Rostasy $K$, Erro ME, Portilla-Cuenca JC, Turón-Viñas E, Málaga I, Muñoz-Cabello B, Torres-Torres C, Llufriu S, González-Gutiérrez-Solana L, González G, Casado-Naranjo I, Rosenfeld M, Graus F, Dalmau J; Spanish Prospective Multicentric Study of Autoimmunity in Herpes Simplex Encephalitis. Autoimmune post-herpes simplex encephalitis of adults and teenagers. Neurology. 2015;85:1736-43.

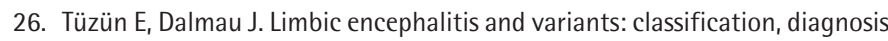
and treatment. Neurologist. 2007;13:261-71.

27. Venkatesan A. Advances in Infectious Encephalitis: Etiologies, Outcomes, and Potential Links with Anti-NMDAR Encephalitis. Curr Infect Dis Rep. 2013;15:594-9.

28. Westman G, Studahl M, Ahlm C, Eriksson BM, Persson B, Rönnelid J, Schliamser $\mathrm{S}$, Aurelius E. N-methyl-D-aspartate receptor autoimmunity affects cognitive performance in herpes simplex encephalitis. Clin Microbiol Infect. 2016;22:934-40.

29. Armangue $T$, Spatola $M$, Vlagea $A$, Mattozzi $S$, Cárceles-Cordon $M$, Martinez-Heras E, Llufriu S, Muchart J, Erro ME, Abraira L, Moris G, MonrosGiménez L, Corral-Corral İ, Montejo C, Toledo M, Bataller L, Secondi G, Ariño H, Martínez-Hernández E, Juan M, Marcos MA, Alsina L, Saiz A, Rosenfeld MR, Graus F, Dalmau J; Spanish Herpes Simplex Encephalitis Study Group. Frequency, symptoms, risk factors, and outcomes of autoimmune encephalitis after herpes simplex encephalitis: a prospective observational study and retrospective analysis. Lancet Neurol. 2018;17:760-72.

30. Zhang SY, Casanova JL. Inborn errors underlying herpes simplex encephalitis: From TLR3 to IRF3. J Exp Med. 2015;212:1342-3.

31. Sironi M, Peri AM, Cagliani R, Forni D, Riva S, Biasin M, Clerici M, Gori A. TLR3 Mutations in Adult Patients With Herpes Simplex Virus and VaricellaZoster Virus Encephalitis. J Infect Dis. 2017;21:1430-4.

32. Wnęk M, Ressel L, Ricci $E$, Rodriguez-Martinez $C$, Guerrero JC, Ismail Z, Smith C, Kipar A, Sodeik B, Chinnery PF, Solomon T, Griffiths MJ. Herpes simplex encephalitis is linked with selective mitochondrial damage; a post mortem and in vitro study. Acta Neuropathol. 2016;132:433-51.

33. Casrouge A, Zhang SY, Eidenschenk $C$, Jouanguy $E$, Puel $A$, Yang $K$, Alcais A, Picard C, Mahfoufi N, Nicolas N, Lorenzo L, Plancoulaine $S$, Sénéchal $B$ Geissmann $F$, Tabeta $K$, Hoebe $K$, Du X, Miller RL, Héron B, Mignot $C$, de Villemeur TB, Lebon P, Dulac 0, Rozenberg F, Beutler B, Tardieu M, Abel L, Casanova JL. Herpes Simplex Virus Encephalitis in Human UNC-93B Deficiency. Science. 2006;314:308-12.

34. Dex Enceph clinical trial registration. ClinicalTrials.gov PRS: 38RC16.015 (French study), and EudraCT: 2015-001609-16 (UK study). 